\title{
How Does Personality And Sociodemographic Characteristics Affect Attitudes Towards Cute Products? The Case of Turkey ${ }^{{ }^{*}}$
}

\author{
Kişilik ve Sosyodemografik Özellikler Sevimli Ůrüinlere Yönelik Tutumlari Nasil \\ Etkiler? Türrkiye Örneği \\ Deniz Ünal ADIGÜZEL ${ }^{2}$ \\ Süleyman BARUTÇU 3a
}

2 Pamukkale Üniversitesi, Bekili Meslek Yüksekokulu, dadiguzel@pau.edutr Orcid ID: 0000000262757434

3 Pamukkale Üniversitesi, IİBF İşletme Bölümü, sbarutcu@pau.edutr Orcid ID: 0000000338980588

a Sorumlu yazar/Responsible author

$\begin{array}{ll}\text { Article Info: } & \text { Research Article } \\ \text { Date Submitted: } & 11.03 .2021 \\ \text { Date Revised: } & 25.03 .2021 \\ \text { Date Accepted: } & 26.03 .2021\end{array}$

\section{Abstract}

The purposes of this study are to determine whether attitudes towards cute products depend on consumer personalities and to reveal the personality and demographic characteristics of individuals who are most sensitive towards cute stimuli and products. Descriptive research and face-to-face survey methods were used to collect primary data. According to the research conducted to identify the individuals with the most positive attitude towards cute products, it is possible to list these personality and sociodemographic characteristics: women; individuals in the 35-54 age range; individuals of non-neurotic personality types, particularly individuals with openness personality types; and individuals with hedonic structure. Moreover, although neurotic personality types don't like cute products results show that if we support marketing efforts with hedonic factors, then neurotic consumers become positive towards cute products.

Keywords: Cuteness, Cuteness Marketing, Cute Products, Personality, Consumer Attitudes

JEL codes: $M 31$

$\begin{array}{ll}\text { Makale Bilgisi: } & \text { Araştırma Makalesi } \\ \text { Geliş Tarihi: } & 11.03 .2021 \\ \text { DüzeltmeTarihi: } & 25.03 .2021 \\ \text { Kabul Tarihi: } & 26.03 .2021\end{array}$

\section{Özet}

Bu çalışmanın amacı, sevimli ürünlere yönelik tutumların tüketici kişiliklerine bă̆lı olup olmadığını belirlemek ve sevimli uyaranlara ve ürünlere en duyarl olan bireylerin kişilik ve demografik özelliklerini ortaya çıkarmaktır. Çalışmada birincil verileri toplamak için tanımlayıcı araştırma ve yüz yüze anket yöntemleri kullanılmıştır. Araştırma sonuçlarına göre sevimli ürünlere en olumlu tutuma sahip bireylerin demografik ve kişilik özellikleri; kadın, 35-54 yaş aralığındaki bireyler; nevrotik olmayan kişilik tiplerine sahip bireyler, özellikle açık kişilik tiplerine sahip bireyler; ve hedonik tüketim şekline sahip bireyler olarak sıralanabilir. Bunun dışında, nevrotik kişilik tiplerinin sevimli ürünlere olumsuz tutum göstermelerine ragmen, sonuçlar pazarlama çabalarmın hedonik faktörlerle desteklenmesi durumunda, tüketicilerin sevimli ürünlere daha olumlu tutuma sahip olduğunu göstermektedir.

Anahtar Kelimeler: Sevimlilik, Sevimlilik Pazarlamasi, Sevimli Ürünler, Kişilik, Tüketici Tutumları

JEL kodlarn: M31

\footnotetext{
1. Yazarlar bu çalışmanın tüm süreçlerinin araştırma ve yayın etiğine uygun olduğunu, etik kurallara ve bilimsel atıf gösterme ilkelerine uyduğunu beyan etmişlerdir. Aksi bir durumda Pamukkale Journal of Eurasian Socioeconomic Studies Dergisi sorumlu değildir. İntihal raporu alınmıştır.

The authors declared that all processes of this study comply with research and publication ethics, and comply with ethical rules and scientific citation principles. Otherwise, Pamukkale Journal of Eurasian Socioeconomic Studies is not responsible. A plagiarism report is received.

* Bu çalışma "Tüketici Davranışı Açısından Sevimlilik Pazarlaması: Kişilik Tipleri ve Sevimli Ürünlere Yönelik Tutum Arasındaki İlişkinin Belirlenmesine Yönelik Bir Araştırma" başlıklı Doktora tezinden türetilmiştir
} 


\section{GENIŞLETILMIŞ ÖZET}

Çalışmanın Amacı: Çalışma üç önemli temel amaç üzerine kurulmuştur. Amaçlar (1) bireylerin sevimli ürünlere yönelik tutumlarının belirlenmesi, (2) sevimli ürünlere yönelik tutumda kişilik tiplerinin etkili olup olmadığının belirlenmesi ve (3) sevimli ürünlere yönelik en olumlu tutuma sahip bireylerin kişilik ve demografik özelliklerinin ortaya çıkartılması olarak siralanabilir.

Alışveriş görevini üstlenen her birey alışveriş yaptığı yerlerde, televizyon izleyen her birey reklamlar aracılığıyla, yazılı ya da sözlü medya kullanan her birey bir şekilde sevimlilik ile ilgili uyarıcılara mutlaka maruz kalmaktadır. Bu bazen bir ürün, bazen bir reklam müziği, bazen yazım karakteri bazen de normal hayatta anlamı olmayan ancak anlam yüklendikten sonra zihinlerimizde artık anlamlı hale gelen sesler (Word Kart'ın Wadaaa sesi çıkartan Wada maskotu gibi) olabilmektedir. Sevimlilik unsuru kadınlara yönelik ürünlerde daha yaygın görülmekle birlikte, erkeklere yönelik ürünlerde de (oto kokuları gibi) görülmeye başlamıştır. Çünkü pazarda artarak alıcı bulan hatta yeni bir pazarlama sahası olarak ortaya çıkmış olan sevimlilik, pazarlama literatüründe yeterli yer almamaktadır. Bu nedenle çalışma hem literatüre hem de pazarlama sektörüne sağladı̆̆ 1 katkılar bakımından oldukça önemlidir.

Sevimlilik konusunda yeterli miktarda çalışmanın yapılmamış olması ve konunun tüketiciler tarafından tam olarak anlaşılamıyor olması sektördeki önemli bir eksiklik olarak görülmekte, en azından sevimliliğe yönelik olumlu tutum sergileyen tüketici özelliklerini belirleyecek bir çalışmanın pazarlama yöneticilerine yol göstermesi beklenmektedir. Sonuç olarak bu çalışmanın amacı, sevimli ürünlere yönelik tutumların tüketici kişiliklerine bağlı olup olmadığını belirlemek ve sevimli uyarıcılara ve ürünlere en duyarlı olan bireylerin kişilik ve demografik özelliklerini ortaya çıkarmaktır.

Araştırma Soruları: Çalışmanın amacına uygun olarak araştırmada; sevimli ürünlere yönelik tutum ile kişilik tipleri arasında ilişkinin olup olmadığı, sevimli ürün satın almak ile sevimli ürünlere yönelik tutum arasında olumlu bir ilişkinin var olup olmadığı, sevimli ürünlere yönelik tutumun ve devamında satın alma niyetinin cinsiyete göre farlılık gösterip göstermediği, çocuk sahibi olmanın sevimli ürünlere yönelik tutumda ve sevimli ürün satın alma niyetinde farklılığa sebep olup, medeni durumun sevimli ürünlere yönelik tutum üzerindeki etkisi olup olmadığı, medeni durumun sevimli ürünlere yönelik satın alma niyeti üzerindeki etkisi olup olmadığı, farklı yaş gruplarına göre sevimli ürünlere yönelik tutum ve satın alma niyetlerinin farklılık gösterip göstermediği, kişilik tiplerinin, duygusal etkinin, sosyal etkinin ve hedonik satın alma değerinin sevimli ürünler üzerindeki etkilerinin nasıl olduğu, duygusal etkinin, sosyal etkinin, hedonik satın alma değerinin ve sevimli ürünlere yönelik tutumun sevimli ürün satın alma niyeti üzerindeki etkilerinin nasıl olduğu sorularına cevaplar aranmıştır.

Literatür Araştırması: Pazarlama dünyasında tüketici algısına eklenilen son eğilimlerden birisi sevimlilik olgusudur. Bunun temel nedeni, ürünün görünen özelliklerinin tüketici kararlarında ve tercihlerinde oldukça etkili olmasıdır. Sevimlilik ile ilgili önceki yıllarda yapılan bazı çalışmalar; Kovarovic (2011), Granot ve arkadaşları (2014), Scott ve Nenkov (2014), Barutçu ve Adıgüzel (2015) şeklindedir. Kişilik ile ilgili ise çalışma sayısı oldukça fazladır; Lin (2010, Otero-Lopez ve Pol (2013), Fayez ve Labib (2016), Hu ve Kim (2018) kişilik 
ile ilgili yapılmış olan çalışmalardan bazılarıdır. Ancak yapılan literatür taramasında ürünlerde sevimlilik ve kişilik tipleri ana fikrine oturtulmuş farklı bir çalışmaya rastlanılmamıştır.

Yöntem: Yöntem olarak tesadüfi olmayan örnekleme yöntemlerinden amaçlı örnekleme yöntemi tercih edilmiştir. Örneklemde çeşitliliği arttırmak için mümkün olduğunca farklı ilçelerde ve farklı sosyo-kültürel ve ekonomik özelliklere sahip katılımcılara ulaşılmaya çalışılmıştır. Araştırma verileri beş aylık bir sürede, yüz yüze anket yöntemi kullanılarak toplanmıştır. Anket formu ilk sayfa da sevimli ürünlere yönelik bilgilendirme olmak üzere iki sayfadan ve toplam altmış yedi sorudan oluşmaktadır. Veri toplama işlemine geçmeden önce dört adet pilot çalışma uygulanmış olup bu çalışmalarda hem anket formunun uygunluğu hem de ölçeklerde bulunan soruların anlaşılırlığı kontrol edilmiş ve nihai anket formuna ulaşmıştır.

Sonuç ve Değerlendirme: Tanımlayıcı araştırma sonuçlarına göre sevimli ürünlere en olumlu tutuma sahip bireylerin demografik ve kişilik özellikleri; kadın, 35-54 yaş aralığındaki bireyler; nevrotik olmayan kişilik tiplerine sahip bireyler, özellikle açık kişilik tiplerine sahip bireyler; ve hedonik tüketim şekline sahip bireyler olarak sıralanabilir. Sonuçlar, pazarlama yöneticilerinin hedef tüketicilere yönelik pazarlama stratejileri hazırlamalarına yardımcı olabilecek tüketici özelliklerini gösterir. 


\section{INTRODUCTION}

Offering products and services that will increase consumer perceptions or attract consumer attention more often than those offered by competitors is very important. Marketers have many tools for increasing customer perception. One of the latest trends is the cuteness phenomenon. There are many studies about cuteness, for example, relating to baby schemes (the basis of cuteness; Lorenz, 1943), cuteness and Japan (Kinsella, 1995), cuteness in the real world and natural designs (Papanek, 1995), cuteness and cool (coolness; Cross, 2004), pioneer of cute (Ngai, 2005), the power of cuteness (Chuang, 2005), a view of Japanese cuteness culture (Lee, 2005), the need for cuteness in the language (Bryce, 2006), change of leadership and the effect of cuteness on soft power (Nye, 2006), cuteness factors (Angier, 2006), forms of cuteness (Ohkura et al., 2008), cuteness in digital media (Cheok et al., 2008), satisfaction and protection feelings of cuteness (Glocker et al., 2009), cuteness as the language of communication (Möller, 2009), to be cute is not to be cool (Aksoy, 2010), answers to cuteness by gender (Lobmaier et al., 2010), loveliness in cars (Taylor, 2011), an example of cuteness Hello Kitty (Kovarovic, 2011), cute colours (Komatsu, 2011), consumption of cuteness in Japan (Decatur, 2012), cuteness in communication (Cheok \& Fernando, 2012), the need to protect objects with cute images (Nittono et al., 2012), description of entertainment and aspects related to cute (Brougere, 2013), comparison of cute with luxury products (Park et al., 2013), socio-cultural analysis of cuteness (Granot et al., 2014), the effect of cuteness on consumption (Nenkov\& Scott, 2014), cuteness and mascots (Barutçu \& Adigüzel, 2015), cuteness as a developing area (Dale, 2016), dimensions of cuteness (Adigüzel et al., 2017) and, finally, a literature review on the topic of cuteness perception which discussed the methods, consequences and moderators in awakening cuteness (Zhipeng et al., 2018). Thus, cuteness can be commonly seen in product, mascot and brand designs, integrated with psychology, sociology and marketing concepts. Cuteness is especially used in marketing as a communication tool to increase customer patience and carefulness. Within the framework of cute marketing concepts and effective product, brand and mascot designs, companies could have a strong marketing tool and gain a competitive advantage (Barutçu \& Adıgüzel, 2015). However, according to Zhipeng et al.'s (2018) literature review, even though there have been many studies, the value of cuteness is not completely understood by marketers.

Most people like to play with cute teddy bears, babies, cars, etc. at some point in their lives. When we start to learn a language, picture stories depict mostly cute animals, people and objects. What is cuteness as we see it in these works? Why is cuteness important to people? Granot et al. (2014, p. 75) answered that question by describing the meaning of cuteness; these authors defined cuteness as a phenomenon that emotionally melts people's hearts and creates a sense of desire for consumers. Cross (2004) defined cuteness as positive emotions as a small child, which must be protected and are at the same time as sincere and natural (Brougere, 2013, p. 345). According to Papanek (1995), cuteness is a small or young person or something that is joyful and entertaining (Demirbilek, 2006, p. 694). Cheok and Fernando (2012, p. 301) argued that cuteness causes feelings such as sweet, innocent, funny, sweetness, cheerfulness or happiness. Zhipeng et al. (2018) defined cuteness as a set of favorable and adorable characters created by cuteness perceptions through manipulation of the offering's color, size and personality, with cuteness originally found among children and females. 
When viewed from an etymological perspective, it is observed that the known concept of cuteness was used by American students in the 1830s-1840s with the meanings of lovely, sweet and attractive. The term is semantically differentiated due to some features of infancy. As a common term in the 1930s-1940s, cuteness was researched by Uexkull who engaged in biology, psychology and ethological research with his work on 'Meaning Theory' and Konrad Lorentz who created an Infant Diagram (Kindchenschema; Möller, 2009, p. 5). According to Lorenz (1943), the physical characteristics of babies, a relatively large face compared to body size, rounded and protruding cheeks, relatively low placement of large eyes in the face and soft elastic surface texture, are suggested to be the shape of a round body; the stimulus appears cute when combined together. Many studies in the literature recognise Lorenz' definition (Allison, 2003; Chuang Tzu-i, 2005; Ngai, 2005; Möller, 2009; Hellen and Saaksjarvi, 2013; Brougere, 2013, p. 345). Cuteness has been socio-culturally labelled with emotional, evaluative images (innocent, nostalgic, rich, cheerful, unique, etc.), and has become a sympathetic, intimate, versatile tool for personality presentations (Bryce, 2006, p. 2272).

Cuteness is not an ordinary word that can be explained by aesthetics because cuteness is not necessarily a concept that is physically sympathetic or attractive. Granot et al. (2014) believed that cuteness is built with highly complex components formed around a simple core structure. This knitted structure consists of the relations between the personal and social identities of consumers and the creation of cultures that embody the world in which they live, their experiences, the processes of gaining experience and the natural and social dynamics of consumer culture. Each individual has a perception area shaped by different socio-economic factors, such as culture, social class and advisory group, and marketing managers need to establish a positive link between consumer perceptions and the products the company produces. The reflections of emotional factors on the consumer can shape consumer perception because people can decide based on the effect of their feelings. At this point, the cuteness and the marketing link should be well established.

\section{CONCEPTUAL FRAMEWORK}

\subsection{Cuteness Marketing and Marketing Mix}

Marketing managers have learned that they can adapt the cute products consumers would accept to the market (Granot et al., 2014, p. 69). Many organizations have achieved high success using the cuteness factor. There are millions of cute objects produced by Elmo, Furby, My Little Pony, Hello Kitty, Pokemon and many more. As an example Sanrio, Hello Kitty's creator, with the release of 15,000 products, Hello Kitty has earned Sanrio three billion dollars a year (Granot et al., 2014, p. 72). As defined by Konrand Lorenz, cuteness marketing can be described as 'marketing activities which are affected the emotions of the consumers by differentiating designed the product, product packaging, design, brand and advertisement to increase the interest of consumers in the target market and increase their purchasing demands by highlighting the cuteness'. Cuteness triggers happiness and compassion, and is therefore widely used in product designs (Demirbilek \& Şener, 2003, p. 1354-1355). As a result of cuteness, the attributed of attractiveness, rememberability and retention are increasing and, as a result, the success of the user experience is expected to increase (Marcus, 2002, p. 29). For this reason, it is important to look at cuteness marketing in light of the marketing mix and to define the cuteness marketing in the literature. We use in our daily lives products are presented to 
the consumer in the form of cute products in order to create a sensation or to create a provocative use. Granot et al. (2014) found that products which are cute, lovely and reassuring increased consumption demand. there are plenty of cute products for adults on the market. From kitchen tools and office supplies, fun colours and shapes, notebook covers with humorous patterns to cute cars like the Fiat 500 and Mini Cooper, cute products are all over the market (Scott \& Nenkov, 2016, p. 323). Price is another factor to effect cute product. Many studies in various fields show that babies and animals (real or photographic) affect the social behaviour of people around them. For example, people are more willing to respond to a survey when they have a baby or a puppy picture in a shopping centre (Bellfield et.al., 2011). Adıgüzel et al. (2017, p. 49), found that when the prices are similar for a product with a cute design as for normally designed products, the participants preferred the cute design. It has been found that in-store lighting in general increases the desire of individuals to examine a product, and light colours used in a store give a feeling of refreshment and calm, while bright colours and signs create excitement for consumers (Areni \& Kim, 1994, p. 121). Sometimes products that seem unnecessary become meaningful when they are cute and in this way create positive emotions in the consumer (Granot et.al., 2014, p. 83). In terms of creative marketing strategies, cuteness has a psychological appeal for some people. Psychologically, cute mascots can break down emotional barriers and, more importantly, create strong connections with consumers. Brand mascots or characters also contribute to brand identity and make the brand more memorable. The overall impact of brand identity and rememberability increases the likelihood of consumers buying these products, and such feelings for the mascot may have similar effects on the brand (Brown, 2010, p. 212).

\subsection{Personality}

In English, the word 'personality' is based on the Latin word 'persona'. Because classical Roman theatre actors were unlikely to be noticed due to the distance between the stage and the audience, instead of the mimic, the actors would reflect their emotions and persona with the masks they wore. In this way, the differences between individuals and personalities are mentioned (Eroğlu, 2015, p. 217; Morgan, 2010, p. 286). Although there is not a single definition of personality, the common point at which almost all writers and thinkers meet is: character, temperament and ability to be composed of three components (Solomon, 2013, p. 237; Atkinson et al., 1995, p. 523; Eren, 2006, p. 83; Burger, 2006, p. 23; Koç, 2012, p. 274; Robbins \& Judge, 2013, p. 165; Kotler \& Armstrong, 2016, p. 177).

Features that compose personality include character, temperament and talent. The personality structure of each individual, who is not confronted with a situation that creates a personality disorder, is composed of different aspects of these three components. Because each individual is affected by the components in question, each individual has different personality characteristics. Studies of the comprehension of personality by leading psychologists consist of research with individuals to define consistent behaviour patterns and internal personality processes. The five-factor personality model, which dates back a long time, is seen as a new perspective on personality. The reason for this is that it is based on scientific observations rather than on theoretical knowledge, which is different from previous perspectives (Demirci et al., 2009, p. 21). The five-factor personality theory is based on the assumption that personality differences can be categorised by the words used in all spoken languages (Pittenger, 2004, p. 780). Scientists think that people have different personality traits and these 
characteristics are measurable. The study of features was first initiated by Allport and Odbert in the 1930s and continued by Cattell in the 1940s and by Tupes, Christal and Norman in the 1960s (John \& Srivastava, 1999, p. 102-105).

The work of determining the characteristics of personality gained a different dimension in the late 1970s from the work of Robert McCrae and Paul Costa in the early 1980s. McCrae and Costa created a detailed classification using simple factor analysis techniques to examine the stability and structure of personality rather than to establish hypotheses of personality traits (Feist \& Feist, 2008, p. 420). Researchers who had been working in three dimensions until 1985 discovered that personality had basically five dimensions and developed a tool to measure these five dimensions. This tool has since been revised and has become widely used (McCrae \& John, 1992; Feist \& Feist, 2008, p. 421; İnanç \& Yerlikaya, 2011, p. 286-287). The five main personality traits that McCrae and Costa discovered as a result of their studies of factor analysis are extraversion, neuroticism, openness (openness to experience), conscientiousness and agreeableness.

Extraversion people are those who like to have fun; they are loving, joking, strong and talkative in terms of social relations (Costa \& McCrae, 1992, p. 5; McCrae \& Costa, 2006, p. 53). People in the dimension of neuroticism are emotional individuals whose anxiety levels are high, they are insecure towards others and they have developed feelings of pity towards themselves (Costa \& McCrae, 1987, p. 301; İnanç \& Yerlikaya, 2011, p. 288). In contrast to the individuals who have closed themselves to establishing relationships with people, the core of openness personality traits is being comfortable about contacting people and other phenomena and pursuing continuous and different experiences (Feist \& Feist, 2008, p. 421; McCrae \& Sutin, 2009, p. 258-259). Individuals with conscientiousness personality characteristics have strong characteristics in terms of maintaining harmonious, altruistic, humble, gentle, outspoken and reliable social relations (McCrae \& Costa, 2008, p. 167; Feist \& Feist, 2008, p. 423). In the agreeableness factor, people can be easily organised, ambitious, success-oriented, regular, controlled, disciplined, hard-working, punctual and ambitious (Digman \& Takemoto-Chock, 1981, p. 168; Feist \& Feist, 2008, p. 423).

\subsection{Personality in Marketing and Consumer Behavior}

Information on consumer characteristics plays a very important role in many marketing applications, such as defining the market for a product or deciding on techniques to be used when targeting products to a particular consumer group (Solomon et al., 2013, p. 4). One of the important concepts that can give ideas of consumer characteristics to marketing managers is the concept of personality because personality has an effect on consumption. According to the results of research conducted in the United States, it was determined that coffee drinkers were more social. In Nescafe ads, the role that the product plays in developing social relationships is strongly emphasised (Koç, 2012, p. 274). The product or service used by an individual can help other individuals to explain their social identity (Solomon et al., 2013, p. 158). McVeigh (2000, p. 234) found that people repeatedly buy Hello Kitty's different designs and express their personality traits with these products.

Objects for sociality can be used. Individuals with a weaker social aspect who choose to live in a more isolated manner satisfy their social needs with anthropomorphised inanimate objects (Epley et al., 2008, p. 114; Tai et al., 2011, p. 619). Psychologically, cute and anthropomorphic 
mascots can break down emotional barriers and create strong connections with important consumers (Soltani et al., 2018, p. 167). The way in which an individual interacts with cute objects displays his or her personality through anthropomorphic ways. In other words, the individual is interpreting him- or herself objectively (Gn, 2016, p. 53). According to some, cuteness has the comforting power to fill people's emotional gaps (Steinberg, 2016). In this context, cuteness has an impact on the sensuality of personality because people establish a connection with the object and are positively affected by their relationship with the object. For example, teddy bears seem cute because they have a look that evokes a feeling of love and affection. Therefore, it is desirable to have the emotional benefits of teddy bears but not because of the benefits of the product (Gn, 2016, p. 50). Japanese firms, services and even banks have long used cute characters in marketing communications. If you are using a fun and cute mascot, you can assume that people are cheerful, fun and harmonious (Kato, 2002; Granot et al., 2014, p. 73).

This is important in terms of marketing the concept of personality, which constitutes the cyphers of personal behaviours and affects consumption preferences. It is of the utmost importance to examine the concept of personality in the more effective implementation of cuteness marketing, a concept that has recently grown into the world of marketing. For this reason, the aim of the research section of the study is to bring many branches of science together, such as marketing, consumer behaviours and psychology as well as cuteness marketing, in order to fill the gap in the literature.

The concept of personality, which forms the behavioural codes of individuals and affects their consumption preferences, is very important in terms of marketing, as reflected in the studies. Although the subject of psychology is part of many disciplines, the five-factor personality model for personality measurement has also found a place in marketing and is very commonly used in marketing today. Many researchers (Mowen \& Spears, 1999; Paunonen \& Ashton, 2001; Barbaranelli et al., 2003; Fraj \& Martinez, 2006; Mulyanegara et al., 2009; Lin, 2010; Casidy, 2012; Atak, 2013; Otero-Lopez \& Pol, 2013; Özsoy et al., 2014; Guido et al., 2015; Liu et al., 2017; Hu \& Kim, 2018) have adopted the five-factor personality model and obtained important findings supporting these five factors in their studies in different cultures and in different languages.

\section{RESEARCH METHODOLOGY, QUESTIONNAIIRE DESIGN AND SAMPLING}

The study is based on three main objectives: (1) to determine attitudes towards cute products; (2) to determine whether personality types affect attitudes towards cute products; and (3) to reveal the personality and demographic characteristics of individuals with the most positive attitudes towards cute products. For these objectives, alternative hypotheses are developed as following;

H1: There is a relationship between attitude towards cute products and personality.

$\mathrm{H} 2$ : There is a positive relationship between attitude towards cute products and buying intention.

H3a: The attitude towards cute products shows a significant difference according to gender.

$\mathrm{H} 3 \mathrm{~b}$ : The intention of buying cute products varies significant difference according to gender. 
H4a: Having a child/children leads to differences in attitude towards cute products.

H4b: Having a child/ children differs the intention of buying cute products.

H5a: The attitude towards cute products shows a significant difference according to marital status.

H5b: The intention of buying cute products varies significant difference according to marital status.

H6a: The attitude towards cute products shows a significant difference according to age range.

H6b:The intention of buying cute products varies significant difference according to age range.

H7: Personality, emotional effect, social effect and hedonism predict attitude towards cute products.

H8: Emotional effect, social effect, hedonism and attitude towards cute products predict the intention of buying cute products.

Survey methodology has been used. The survey questions about personality, hedonic and utilitarian buying value, attitude and buying intention were adopted from John and Srivastava (1999), Babin et al. (1994), Sweeny and Soutar (2001), Yoo and Donthu (2001) and Wen and Li (2013). There were sixty-five questions in five sections in the structured questionnaire. In the first section, five questions with nominal scales asked about the characteristics of respondents; in the second section, thirty questions with interval scales were used to determine the personality; the third section consisted of thirteen questions on hedonic and utilitarian buying value; the fourth included eleven questions on attitudes towards cute products; and the fifth section contained five questions on attitudes towards buying cute products.

The questionnaire was pre-tested three times by a total of one hundred students in order to construct the validity of the measurement scale. The survey sample frame was individuals over 15 years of age who have the potential to make purchases and live in Istanbul, Ankara, İzmir and Denizli cities. Data with a sample size of 1,000 was determined among 20,283,216 people, but after that 1,050 data size was reached. A purposeful sampling method was chosen as one of the non-random sampling methods.

The reliability of the questionnaire was assessed by the Cronbach alpha reliability coefficient. Reliability value was calculated for extraversion personality as 0.778 , conscientiousness personality 0.765 , neuroticism personality 0.710 , agreeableness personality 0.713 , openness personality 0.831 , hedonic buying value 0.890 and utilitarian buying value 0.700 , for attitudes towards cute products 0.767 , for emotional effect 0.893 , for social effect 0.830 and for attitudes towards buying cute products 0.907 . The skewness kurtosis values of the research were examined. The overlap of the values observed with these values ( -1 between +1 ; Morgan et al., 2011) and the normal distribution values in the Q-Q plots indicates that the normality of the distribution is acceptable. SPSS 21.0 for Windows was used to analyse data with descriptive statistics, correlation, T-Tests, ANOVA and hierarchical regression analysis.

\subsection{Findings}

Descriptive statistics are given in Table 1 with regard to gender, marital status, age, education, personal income and number of children. Survey participants returned 1,050 questionnaires. 
As seen in Table 1, among the 1,050 respondents, $47.3 \%$ were females; $81.6 \%$ were between the ages of $15-54 ; 54.4 \%$ were married; $53.1 \%$ had a maximum education level of a high school graduate; $64.2 \%$ of the respondents had a monthly income that was between 2001TL-6000TL; and $54.8 \%$ had a child or children.

Table 1: Respondents' Profile

\begin{tabular}{|c|c|c|c|c|c|}
\hline Gender & $\mathbf{N}$ & $\%$ & Income & $\mathbf{N}$ & $\%$ \\
\hline Female & 497 & 47,3 & 2000TL and Less & 147 & 14,0 \\
\hline Male & 553 & 52,7 & 2001-4000TL & 301 & 28,7 \\
\hline Total & 1050 & 100,0 & 4001-6000TL & 373 & 35,5 \\
\hline Marital Sta. & $\mathbf{N}$ & $\%$ & 6001-8000TL & 217 & 20,7 \\
\hline Single & 479 & 45,6 & 8001TL and More & 12 & 1,1 \\
\hline Married & 571 & 54,4 & Total & 1050 & 100,0 \\
\hline Total & 1050 & 100,0 & Education & $\mathbf{N}$ & $\%$ \\
\hline Age & $\mathbf{N}$ & $\%$ & Primary Sch. & 209 & 19,9 \\
\hline $15-24$ & 228 & 21,7 & High Sch. & 349 & 33,2 \\
\hline $25-34$ & 192 & 18,3 & University & 462 & 44,0 \\
\hline $35-44$ & 259 & 24,7 & Post Graduate & 30 & 2,9 \\
\hline $45-54$ & 177 & 16,9 & Total & 1050 & 100,0 \\
\hline $55-64$ & 126 & 12,0 & Having Child & $\mathbf{N}$ & $\%$ \\
\hline 64-Upper & 68 & 6,5 & Yes & 575 & 54,8 \\
\hline \multirow[t]{2}{*}{ Total } & 1050 & 100,0 & No & 475 & 45,2 \\
\hline & & & Total & 1050 & 100,0 \\
\hline
\end{tabular}

In order to measure the hypotheses of H1, H1a, H1b, H1c, H1d and H1e based on the assumption that there may be a relationship between the factors affecting attitudes towards cute products, personality types were correlated with the attitudes towards cute products.

H1: There is a relationship between attitude towards cute products and personality.

H1a: There is a positive relationship between attitude towards cute products and extraversion personality type.

$\mathrm{H} 1 \mathrm{~b}$ : There is a positive relationship between attitude towards cute products and conscientiousness personality type.

H1c: There is a positive relationship between attitude towards cute products and neuroticism personality type.

H1d: There is a positive relationship between attitude towards cute products and agreeableness personality type.

H1e: There is a positive relationship between attitude towards cute products and openness personality type.

When Table 2 is examined, it can be seen that openness to innovations personality type indicates a moderate and positive relationship towards attitudes of the participants to cute products $(r=0.305)$. Individuals who enjoy trying new menu items in a restaurant or who are looking for new and exciting restaurants are an example of the openness personality type. Therefore, individuals with the openness personality type are expected to have a positive attitude. The extraversion personality type towards cute products is positive but at a low level $(r=0.299)$. This result differs from what was expected because those with extraversion personality type traits were expected to have the most positive attitude towards cute products. Individuals with agreeableness personality types are those who do not have any problems 
with socialisation and can use their individual characteristics for the learning process (McCrae \& Costa, 2008, p. 167; Feist \& Feist, 2008, p. 423).

Table 2: Correlation Matrix

\begin{tabular}{|c|c|c|c|c|c|c|}
\hline & & Extraversion & Conscientiousness & Neuroticism & Agreeableness & Openness \\
\hline $\begin{array}{l}\text { Attitude Towards } \\
\text { Cute Products }\end{array}$ & $\begin{array}{l}\text { Pearson } \\
\text { Correlation }\end{array}$ &, $299^{* *}$ &, $236^{* *}$ &,$- 115^{* *}$ & ,279** &, $305^{* *}$ \\
\hline
\end{tabular}

Agreeableness personality type participants $(\mathrm{r}=0.279)$ had a positive but low level of attitudes towards cute products. Results were very similar for conscientiousness personality type participants $(\mathrm{r}=0.236)$. This result is normal because individuals with this personality type have slightly more disciplined and serious personality traits than the other three. Unlike other personality types, neuroticism personality type individual attitudes towards cute products expressed a low-level negative relationship $(\mathrm{r}=-0.115)$. According to the analysis results, $\mathrm{H} 1$, H1a, H1b, H1d, H1e hypotheses were accepted. However, the H1c hypothesis was rejected because the analysis shows that individuals with neurotic personality type do not show positive attitudes towards cute products. Again, it can be said that the individuals with the most negative attitudes towards cute products are individuals with neurotic personality traits and the individuals with the most positive attitudes are individuals who have openness personality traits.

The $\mathrm{H} 2$ hypothesis was tested to determine whether the presence of the attitude towards cute products had an effect on the intention of buying cute products.

H2: There is a positive relationship between attitude towards cute products and buying intention.

There is a significant relationship between the attitude towards cute products and buying intention of cute products. This relationship can be said to be a moderate, positive and significant relationship ( $\mathrm{r}=0.584)$, (Table 3$)$. When the determination coefficient $(\mathrm{r} 2=0.34)$ is taken into consideration, it can be said that $34 \%$ of the intention to buy cute products is caused by the attitude towards cute products. In the light of this result, $\mathrm{H} 2$ hypothesis was accepted.

Table 3: Correlation Matrix for the Intention of Buying Cute Products and Attitudes

\begin{tabular}{l|l|l}
\hline \multicolumn{2}{l}{ Attitude Towards Cute Products } \\
\hline $\begin{array}{l}\text { Intention of Buying } \\
\text { Cute Products }\end{array}$ & $\begin{array}{l}\text { Pearson } \\
\text { Correlation }\end{array}$ &, $584 * *$ \\
\hline \multicolumn{2}{c}{$*$ Correlation is significant at the 0.01 level (two-tailed). }
\end{tabular}

Based on the information found in the literature research (Hildebrandt \& Fitzgerald, 1978; Karraker \& Stern, 1990; Wang, 2014, p. 82), in this study, it was aimed to test whether the attitudes of the individuals in the sample towards cute products differ according to gender in light of the answers given by participants to the research. For this purpose, the independent samples T-Test was applied to test $\mathrm{H} 3 \mathrm{a}$ and $\mathrm{H} 3 \mathrm{~b}$ and analysis results are given in Table 4.

H3a: The attitude towards cute products shows a significant difference according to gender.

$\mathrm{H} 3 \mathrm{~b}$ : The intention of buying cute products varies significant difference according to gender. 
Table 4: Independent Sample T -Test for Attitudes towards Cute Products, the Intention of Buying Cute Products and Gender

\begin{tabular}{|c|c|c|c|c|c|c|c|c|}
\hline \multirow{2}{*}{$\begin{array}{l}\text { Attitude } \\
\text { Towards } \\
\text { Products }\end{array}$} & \multirow[b]{2}{*}{ Cute } & Gender & $\mathbf{N}$ & $\bar{x}$ & ss. & sd & t & p \\
\hline & & $\begin{array}{l}\text { Female } \\
\text { Male }\end{array}$ & $\begin{array}{l}497 \\
553\end{array}$ & $\begin{array}{l}3,51 \\
3,05\end{array}$ & $\begin{array}{l}0,91 \\
0.97\end{array}$ & 1048 & 7,85 & $\mathbf{0 , 0 0}$ \\
\hline \multirow{2}{*}{$\begin{array}{l}\text { Intention } \\
\text { Buying } \\
\text { Products } \\
\end{array}$} & \multirow{2}{*}{$\begin{array}{r}\text { of } \\
\text { Cute }\end{array}$} & Gender & $\mathrm{N}$ & $\overline{\mathrm{x}}$ & ss. & sd & $t$ & p \\
\hline & & $\begin{array}{l}\text { Female } \\
\text { Male } \\
\end{array}$ & $\begin{array}{l}497 \\
553 \\
\end{array}$ & $\begin{array}{l}3,36 \\
2,75 \\
\end{array}$ & $\begin{array}{l}0,93 \\
1,04 \\
\end{array}$ & 1047,8 & 9,9 & $\mathbf{0 , 0 0}$ \\
\hline
\end{tabular}

As a result of the analysis conducted on whether the attitudes of the participants towards cute products differ according to gender, the attitude towards cute products shows a significant difference by gender $(\mathrm{t}(1048)=7.85, \mathrm{p}=0.00<0.05)$. The H3a hypothesis was accepted. Female participants' attitudes towards cute products $(=3.51)$ are more positive than male participants' attitudes towards cute products ( $=3.05$ ). The calculated Cohen's d value is 0.48 . Accordingly, it can be observed that the difference between the mean scale scores of females and males is 0.48 standard deviation. As to whether the attitudes of the participants towards the intention of buying cute products differ according to gender, the analysis shows a significant difference according to gender $(\mathrm{t}(1047.8)=9.9, \mathrm{p}=0.00<0.05)$. As a result $\mathrm{H} 3 \mathrm{~b}$ was accepted. The calculated Cohen's d value is 0.61 .

Having a child can cause differences in consumer attitudes and buying decisions. H4a and $\mathrm{H} 4 \mathrm{~b}$ tested that assumption. Results are given in Table 5.

H4a: Having a child/children leads to differences in attitude towards cute products.

H4b: Having a child/ children differs the intention of buying cute products.

Table 5: Independent Sample T -Test For Attitudes towards Cute Products, the Intention of Buying Cute Products and Having Child/Children

\begin{tabular}{l|l|llllll}
\hline \multirow{2}{*}{$\begin{array}{l}\text { Attitude Towards } \\
\text { Cute Products }\end{array}$} & Having Child/Children & $\mathbf{N}$ & $\overline{\mathbf{X}}$ & ss. & sd & $\mathbf{t}$ & $\mathbf{p}$ \\
\cline { 2 - 8 } & Yes & 575 & 3,28 & 0,96 & \multirow{2}{*}{1048} & 0,50 & 0,61 \\
\hline \multirow{2}{*}{$\begin{array}{l}\text { Intention of Buying } \\
\text { Cute Products }\end{array}$} & Having Child/Children & $\mathbf{N}$ & $\overline{\mathrm{x}}$ & ss. & sd & $\mathbf{t}$ & $\mathbf{p}$ \\
\cline { 2 - 8 } & Yes & 575 & 3,14 & 1,00 & \multirow{2}{*}{1048} & \multirow{2}{*}{3,46} & 0,00 \\
\hline
\end{tabular}

Contrary to expectations, the attitudes of the participants towards cute products did not show a significant difference compared to having children $(t(1048)=0.5, p=0.61>0.05)$. Therefore, the $\mathrm{H} 4 \mathrm{a}$ hypothesis was rejected. According to the research, it has been concluded that the amount of buying by individuals who shop with their children increases and that children are also effective in the buying of other products that are not related or that they even make brand choices (McDougall \& Chantrey, 2004, p. 3; Gülerarslan, 2011, p. 127-128). Therefore, H4a investigated whether the intention of buying cute products differed according to having children (Table 5). As a result of the analysis, it was concluded that the intention of buying cute products differed according to having children $(\mathrm{t}(1048)=3.46, \mathrm{p}=0.00<0.05)$. H4b was accepted as a result. Attitudes towards the intention to buy cute products are the average of the participants who have children $(=3.14)$, whereas the participants who do not have children ( =2.92). The calculated Cohen's d value is 0.21 . There is no difference between the participants who have children and the attitude towards cute products, but the difference in the intention to buy cute products and the fact that children have a say in the buying decisions of the research participants are suggestive. Based on this result, it is thought that taking into consideration the children in the activities related to the marketing of cute products and 
carrying out studies that can reach the children even if they are aimed at adults will facilitate the sale of the products.

Marital status can cause differences in consumer attitudes and buying decisions. $\mathrm{H} 5 \mathrm{a}$ and $\mathrm{H} 5 \mathrm{~b}$ tested that assumption. Results are given in Table 6.

H5a: The attitude towards cute products shows a significant difference according to marital status.

$\mathrm{H} 5 \mathrm{~b}$ : The intention of buying cute products varies significant difference according to marital status.

Table 6: Independent Sample T -Test For Attitudes towards Cute Products, the Intention of Buying Cute Products and Marital Status

\begin{tabular}{|c|c|c|c|c|c|c|c|}
\hline \multirow[b]{2}{*}{$\begin{array}{l}\text { Attitude Towards Cute } \\
\text { Products }\end{array}$} & Marital Status & $\mathbf{N}$ & $\overline{\mathrm{X}}$ & ss. & sd & $\mathbf{t}$ & $\mathbf{p}$ \\
\hline & $\begin{array}{l}\text { Single } \\
\text { Married }\end{array}$ & $\begin{array}{l}479 \\
571\end{array}$ & $\begin{array}{l}3,26 \\
3,27 \\
\end{array}$ & $\begin{array}{l}0,96 \\
0,97\end{array}$ & 1048 & 0,25 & 0,80 \\
\hline \multirow{2}{*}{$\begin{array}{l}\text { Intention of Buying } \\
\text { Cute Products }\end{array}$} & Marital Status & $\mathrm{N}$ & $\overline{\mathbf{x}}$ & ss. & sd & $\mathbf{t}$ & p \\
\hline & $\begin{array}{l}\text { Single } \\
\text { Married }\end{array}$ & $\begin{array}{l}479 \\
571\end{array}$ & $\begin{array}{l}2,92 \\
3,13\end{array}$ & $\begin{array}{l}1,08 \\
0,99\end{array}$ & 1048 & 3,30 & 0,00 \\
\hline
\end{tabular}

The analysis that was conducted to determine whether the attitudes of the participants towards cute products differ according to marital status did not show a significant difference $(\mathrm{t}(1048)=0.25, \mathrm{p}=0.80>0.05$; Table 6$)$. H5a was rejected. According to Table 6, it was concluded that the intention of buying cute products differed according to marital status $(t(1048)=3.30$, $\mathrm{p}=0.00<0.05)$. H5b was accepted.

In order to test whether the attitudes of the participants towards cute products differ according to age ranges, the mean attitude of the groups formed according to age ranges towards cute products was compared with one-way ANOVA analysis for unrelated samples.

H6a: The attitude towards cute products shows a significant difference according to age range.

H6b: The intention of buying cute products varies significant difference according to age range.

As seen a result of ANOVA analysis in Table 7, it was found that there was a significant difference between participants' attitudes towards cute products according to age ranges $\mathrm{F}(5$, $1049)=3,083, p=0.00<0.05$ (Table 7). H6a was accepted. The calculated effect size $(\eta 2=0,01)$ indicates that the difference is low (Can, 2017, p. 157). According to the result of LSD test which was done in order to find out the differences between the groups, it was seen that the difference was between the age ranges of 35-44 and 45-54 years. It was found that there was a significant difference between the participants' attitudes towards intention of buying cute products according to age ranges $F(5,1049)=3,566, p=0.00<0.05$ (Table 7). H6b was accepted. According to the results of Dunnett's $C$ test, a significant difference was found between the age ranges of 15-24. In light of these results, which are unlike Kuşanağ 1 (2003, cited in Bryce, 2006, p. 2272), participants proved that they want to buy cute products not only for children but also for older adults in Turkey as in Asian countries. 
Table 7: One -Way ANOVA

\begin{tabular}{|c|c|c|c|c|c|c|c|c|}
\hline \multirow{8}{*}{$\begin{array}{l}\text { Attitude } \\
\text { Towards } \\
\text { Cute } \\
\text { Products }\end{array}$} & Age Range & $\mathbf{N}$ & $\overline{\mathrm{x}}$ & ss. & Sd & $\mathbf{F}$ & $\mathbf{p}$ & Differ. \\
\hline & $15-24$ & 228 & 3,2237 & ,94238 & & & & \\
\hline & 25-34 & 192 & 3,1615 & 1,00665 & & & & \\
\hline & $35-44$ & 259 & 3,4003 & 96929 & & & & \\
\hline & $45-54$ & 177 & 3,4049 & ,94007 & 5-1044 & 3,083 & 0,00 & $35-44$ \\
\hline & $55-64$ & 126 & 3,2063 & ,92073 & & & & \\
\hline & 65 and Upper & 68 & 3,0441 & 1,03649 & & & & \\
\hline & Total & 1050 & 3,2727 & ,96919 & & & & \\
\hline \multirow{8}{*}{$\begin{array}{l}\text { Intention of } \\
\text { Buying } \\
\text { Cute } \\
\text { Product }\end{array}$} & Age Range & $\mathbf{N}$ & $\overline{\mathrm{x}}$ & ss. & Sd & $\mathbf{F}$ & $\mathbf{p}$ & Differ. \\
\hline & $15-24$ & 228 & 2,8430 & 1,07666 & & & & \\
\hline & $25-34$ & 192 & 2,9563 & 1,08341 & & & & \\
\hline & $35-44$ & 259 & 3,1969 & 99299 & & & & \\
\hline & $45-54$ & 177 & 3,1548 & 1,07481 & $5-1044$ & 3,566 & 0,00 & $15-24$ \\
\hline & $55-64$ & 126 & 3,0667 & 88000 & & & & \\
\hline & 65 and Upper & 68 & 3,0235 & 1,03059 & & & & \\
\hline & Total & 1050 & 3,0421 & 1,03882 & & & & \\
\hline
\end{tabular}

Hierarchical regression analyses were conducted to analyse the effects of independent variables of personality types, hedonism behaviours, social effects of cute products and emotional effects of cute products to attitude towards cute products (Table 8).

H7: Personality, emotional effect, social effect and hedonism predict attitude towards cute products.

H7a: Extraversion personality type, emotional effect, social effect and hedonism predict attitude towards cute products.

H7b: Conscientiousness personality type, emotional effect, social effect and hedonism predict attitude towards cute products.

H7c: Neuroticism personality type, emotional effect, social effect and hedonism predict attitude towards cute products.

H7d: Agreeableness personality type, emotional effect, social effect and hedonism predict attitude towards cute products.

H7e: Openness personality type, emotional effect, social effect and hedonism predict attitude towards cute products.

In the first step of hierarchical regression analysis, extraversion personality type entered into the model. In the second step, hedonism entered into the model. In the third step, social effect entered, and in the final step, emotional effect entered the analysis. As a result of the first hierarchical regression analysis, extraversion personality type, hedonism, social effect and emotional effect showed a significant relationship with attitude towards cute products $(\mathrm{F}(4-$ $1045)=208,232$, $\mathrm{p}<0.05$; Table 8) so H7a was accepted. Together, these four variables accounted for $44 \%$ of the attitude towards cute products $(R=0.666, R 2=0.444)$. In the second analysis, conscientiousness personality type, hedonism, social effect and emotional effect showed a significant relationship with attitude towards cute products $(\mathrm{F}(4-1045)=196,407, \mathrm{p}<0.05$; Table 8) so $\mathrm{H7b}$ was accepted. Together, these four variables accounted for $43 \%$ of the attitude towards cute products $(\mathrm{R}=0.662, \mathrm{R} 2=0.438)$. In the third hierarchical regression analysis, neuroticism personality type, hedonism, social effect and emotional effect showed a significant relationship with attitude towards cute products $(\mathrm{F}(4-1045)=187,716, \mathrm{p}<0.05)$, (Table 8) so H7c 
was accepted. Together, these four variables accounted for $41 \%$ of the attitude towards cute products $(\mathrm{R}=0.643, \mathrm{R} 2=0.414)$. There is a negative correlation between neurotic personality type and attitude towards cute products. Therefore, while the neuroticism personality type alone explains only $1 \%$ of the attitude towards cute products $(R 2=0.013)$, this ratio increases to $22 \%$ with the addition of hedonism to the step. The important point here is that there are significant changes in the attitudes of the neurotic personality type individuals who show negative attitudes towards cute products when supported by hedonism. This result shows that hedonic items should be used to influence the attitudes of neurotic personality type individuals towards cute products and hedonism should be paid attention to in marketing activities directed towards these individuals.

Table 8: Summary of Hierarchical Regression Analysis for Personality Types Predicting

\begin{tabular}{|c|c|c|c|c|c|c|c|}
\hline $\begin{array}{l}\text { Dependent } \\
\text { Variable }\end{array}$ & $\begin{array}{l}\text { Independent } \\
\text { Variables }\end{array}$ & Beta & $\mathbf{t}$ & Sig. & $\mathbf{R}$ & $\mathbf{R}^{2}$ & $\mathbf{F}$ \\
\hline \multirow{20}{*}{ 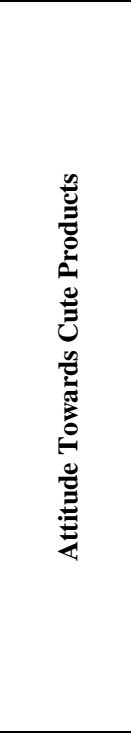 } & Model 1 & , 299 a & $10,125^{\mathrm{a}}$ &, $000^{\mathrm{a}}$ & ,299a &, $089^{\mathrm{a}}$ & $102,518^{\mathrm{a}}$ \\
\hline & Personality Type & $277^{\mathrm{b}}$ & $7,878^{\mathrm{b}}$ &, $000^{b}$ &, $236^{\mathrm{b}}$ &, $056^{\mathrm{b}}$ & $62,067^{b}$ \\
\hline & $\left(\right.$ Extraversion $^{\mathrm{a}}$ &,$- 153^{\mathrm{c}}$ & $-3,761^{\mathrm{c}}$ &, $000^{\mathrm{c}}$ &, $115^{\mathrm{c}}$ &, $013^{\mathrm{c}}$ & $14,142^{\mathrm{c}}$ \\
\hline & $\begin{array}{l}\text { Conscientiousness }{ }^{\mathrm{b}} \text {, } \\
\text { Neuroticism }^{\mathrm{c}}\end{array}$ & $412^{\mathrm{d}}$ & $9,393^{\mathrm{d}}$ &, $\mathbf{0 0 0}^{\mathrm{d}}$ &, $279^{\mathrm{d}}$ &, $078^{\mathrm{d}}$ & $88,230^{\mathrm{d}}$ \\
\hline & $\begin{array}{l}\text { Agreeableness }{ }^{\mathrm{d}}, \\
\text { Openness }^{\mathrm{e}} \text { ) }\end{array}$ &, $305^{\mathrm{e}}$ & $10,366^{\mathrm{e}}$ &, $000^{e}$ &, $305^{\mathrm{e}}$ &, $093^{\mathrm{e}}$ & $107,459^{\mathrm{e}}$ \\
\hline & &, $423^{\mathrm{a}}$ & $15,523^{\mathrm{a}}$ &, $\mathbf{0 0 0}^{\mathrm{a}}$ &, $509^{\mathrm{a}}$ &, $260^{\mathrm{a}}$ & $183,471^{\mathrm{a}}$ \\
\hline & Model 2 &, $473^{b}$ & $16,312^{\mathbf{b}}$ &, $000^{b}$ &, $497^{\mathrm{b}}$ & $247^{\mathbf{b}}$ & $266,089^{b}$ \\
\hline & Personality Type &, $494^{\mathrm{c}}$ & $16,915^{\mathrm{c}}$ &, $000^{c}$ &, $474^{\mathrm{c}}$ &, $225^{\mathrm{c}}$ & $286,124^{c}$ \\
\hline & Hedonism & $456^{\mathrm{d}}$ & $15,474^{\mathrm{d}}$ &, $\mathbf{0 0 0}^{\mathrm{d}}$ & $499^{d}$ & $249^{\mathrm{d}}$ & $239,440^{\mathrm{d}}$ \\
\hline & &, $426^{\mathrm{e}}$ & $15,826^{\mathrm{e}}$ &, $000^{\mathrm{e}}$ &, $518^{\mathrm{e}}$ & ,268 & $250,451^{\mathrm{e}}$ \\
\hline & &, $323^{\mathrm{a}}$ & $11,585^{\mathrm{a}}$ &, $000^{\mathrm{a}}$ &, $586^{\mathrm{a}}$ &, $344^{\mathrm{a}}$ & $182,610^{\mathrm{a}}$ \\
\hline & $\begin{array}{l}\text { Model } 3 \\
\text { Personality Tyne }\end{array}$ &, $325^{\mathrm{b}}$ & $11,523^{b}$ &, $000^{b}$ &, $576^{\mathrm{b}}$ &, $332^{\mathbf{b}}$ & $132,778^{\mathrm{b}}$ \\
\hline & Hedonism &, $323^{\mathrm{c}}$ & $11,241^{\mathrm{c}}$ &, $\mathbf{0 0 0}^{\mathrm{c}}$ &, $556^{\mathrm{c}}$ & ,309 & $126,358^{c}$ \\
\hline & $\begin{array}{l}\text { Hedonism } \\
\text { Social Effect }\end{array}$ &, $331^{\mathrm{d}}$ & $11,728^{\mathrm{d}}$ &, $\mathbf{0 0 0}^{\mathrm{d}}$ &, $580^{\mathrm{d}}$ &, $337^{\mathrm{d}}$ & $137,541^{\mathrm{d}}$ \\
\hline & &, $328^{\mathrm{e}}$ & $11,830^{\mathrm{e}}$ &, $000^{\mathrm{e}}$ &, $595^{\mathrm{e}}$ &, $354^{\mathrm{e}}$ & $139,938^{\mathrm{e}}$ \\
\hline & Model 4 & $441^{\mathrm{a}}$ & $13,691^{\mathrm{a}}$ & $\mathbf{0 0 0}^{\mathrm{a}}$ &, $666^{\mathrm{a}}$ &, $444^{\mathrm{a}}$ & $208,232^{\mathrm{a}}$ \\
\hline & Personality Type &, $411^{\mathrm{b}}$ & $14,015^{\mathbf{b}}$ &, $\mathbf{0 0 0}^{\mathrm{b}}$ &, $662^{\mathrm{b}}$ &, $438^{\mathrm{b}}$ & $196,407^{b}$ \\
\hline & Hedonism &, $410^{c}$ & $13,701^{\mathrm{c}}$ &, $000^{c}$ &, $643^{\mathrm{c}}$ &, $414^{\mathrm{c}}$ & $187,716^{\mathrm{c}}$ \\
\hline & Social Effect & ,399 & $13,578^{\mathrm{d}}$ &, $\mathbf{0 0 0}^{\mathrm{d}}$ &, $660^{\mathrm{d}}$ &, $436^{\mathrm{d}}$ & $184,368^{\mathrm{d}}$ \\
\hline & Emotional Effect &, $433^{\mathrm{e}}$ & $13,486^{\mathrm{e}}$ &, $\mathbf{0 0 0}^{\mathrm{e}}$ &, $671^{\mathrm{e}}$ &, $450^{\mathrm{e}}$ & $181,871^{\mathrm{e}}$ \\
\hline
\end{tabular}

As a result of the fourth hierarchical regression analysis, agreeableness personality type, hedonism, social effect and emotional effect showed a significant relationship with attitude towards cute products $(\mathrm{F}(4-1045)=184,368, \mathrm{p}<0.05$; Table 8$)$ so H7d was accepted. Together, these four variables accounted for $43 \%$ of the attitude towards cute products $(R=0.660, R 2=$ 0.436). Finally, as a result of fifth hierarchical regression analysis, openness personality type, hedonism, social effect and emotional effect showed a significant relationship with attitude towards cute products $(\mathrm{F}(4-1045)=181,871, \mathrm{p}<0.05$; Table 8$)$ so H7e was accepted. Together, these four variables accounted for $45 \%$ of the attitude towards cute products $(R=0.671, R 2=$ 0.450). To summarize the hierarchical regression analyses when the effect of personality types on the attitude towards cute products is examined, openness personality type affects $9 \%$, extraversion personality type $8 \%$, agreeableness personality type $7 \%$, conscientiousness personality type $5 \%$ and neuroticism personality type affects $1 \%$. Due to the fact that cute products are new on the market, the rates are considered to be lower than expected due to the fact that consumers are unfamiliar with products and the main mass is not yet reached. However, according to the results, it can be said that personality types are predictors in the attitude towards cute products. For that reason, H7 was accepted. 
How the emotional effects of cute products, social effects of cute products, hedonism and attitude variables towards cute products predict the intention to buy cute products are presented in Table 9 and tested in $\mathrm{H} 8$.

H8: Emotional effect, social effect, hedonism and attitude towards cute products predict the intention of buying cute products.

As a result of the analysis performed according to Table 9, it is seen that the variables of emotional effect, social effect, hedonism and attitude towards cute products have a significant relationship with the intention of buying cute products $(F(5-1044)=577,323 ; p<0.05)$, thus H8 was accepted. Together, these four variables account for $68 \%$ of the intention of buying cute products.

Table 9: Hierarchical Regression Analysis to Intention of Buying Cute Products

\begin{tabular}{|c|c|c|c|c|c|c|c|}
\hline Dependent & Independent & Beta & $\mathbf{T}$ & Sig. & $\mathbf{R}$ & $\mathbf{R}^{2}$ & $\mathbf{F}$ \\
\hline \multirow{10}{*}{$\begin{array}{l}\text { Intention of } \\
\text { Buying Cute } \\
\text { Product }\end{array}$} & Emotional Effect & ,772 & 39,269 & 000 &, $772^{a}$ & ,595 & 1542,018 \\
\hline & Emotional Effect & ,571 & 25,029 & ,000 & $812^{b}$ & & \\
\hline & Social Effect & ,327 & 14,324 & ,000 &, $813^{\circ}$ & 662 & 1023,812 \\
\hline & Emotional Effect & ,489 & 20,056 & ,000 & & & \\
\hline & Social Effect & 302 & 13,484 & ,000 &, $825^{c}$ & 681 & 745,322 \\
\hline & Hedonism & 172 & 8,024 & ,000 & & & \\
\hline & Emotional Effect & ,439 & 16,808 & ,000 & & & \\
\hline & Social Effect & 289 & 13,002 & ,000 & & & \\
\hline & Hedonism & 154 & 7,152 & 000 & $830^{\mathrm{a}}$ & 688 & 577,323 \\
\hline & Attitude Tow. Cute Pro. & 110 & 4,904 & ,000 & & & \\
\hline
\end{tabular}

According to the analysis, the presence of emotional effects in the intention of buying cute products is $59 \%$. This result shows the importance of the emotional effects to the participants and the increase in their intention to buy cute products.

\section{CONCLUSIONS}

The study's main purpose is to find the personality type or types which have positive attitudes to cute products. For that reason, the first step was testing the relation between personality types to attitudes to cute products. Thus far, there hadn't been any study in the Turkish marketing literature. Another point of this study is related to having a baby or child because literature has shown that having a child or being pregnant has a positive effect on attitudes towards cuteness (Storey et al., 2000; Bryce, 2006, p. 2266). Age range was another researched point because according to literature, attitudes towards cuteness have differentiation in Asian countries as compared to Western countries (Bryce, 2006, p. 2272). One of the most important points of the study is to analyse the effects of personality types, hedonism behaviours, social effects of cute products on society and emotional effects of cute products on attitude towards cute products, which have affected the attitude dependent variable towards cute products in other studies (Adigüzel \& Barutçu, 2017).

To return to the main purpose again: according to the research conducted to identify the individuals with the most positive attitude towards cute products, it is possible to list these individuals: (1) women; (2) individuals in the 35-54 age range; (3) individuals of non-neurotic personality types, particularly individuals with openness personality types; and (4) individuals with hedonic structure. In addition, if we want to look at individuals who have the most positive attitude with the intention of buying cute products, they are: (1) women; (2) individuals with children; (3) individuals who are married; and (4) those outside the 15-24 age 
range. Another important finding is the hedonism factor that increases the attitude of all personality types towards cute products. It was concluded that the personality type neuroticism, which is expected to have a negative attitude as the return of personality traits, especially in the attitude towards cute products as a result of the analysis which supports this expectation, has a significant positive attitude in a marketing effort supported by hedonism. For this reason, it is predicted that marketing activities that will increase hedonism in marketing mix elements (for example, increasing the hedonic atmosphere in the store design [Ballantine et al., 2010], price and quality, as well as the presence of product images and messages) to be used in presenting cute products will generally affect the attitudes of all individuals towards cute products.

It is also seen that the individuals involved in the research give importance to the emotional value of a product as well as its functional value. Therefore, especially when extraversion and conscientiousness personality types are desired to be targeted, it is important to increase the factors that cause emotional effects. It is thought that the activities related to marketing cute products should also be taken into consideration for children and that even studies aimed at reaching children, even if they are intended for adults, will facilitate the sale of products. This is because, in the study, it was concluded that children had no effect on the attitude towards cute products, but that having children was effective in purchasing, which proves the effect of children in the purchasing decision process. Therefore, children should also be taken into consideration in the sale of cute products. This study has been prepared with the theme of 'cute product'. Therefore, it is thought that conducting studies using cute and marketing mix elements, using cute and sensory factors or using cute marketing consumer behaviour interaction will contribute to both researchers and literature.

\section{ACKNOWLEDGMENTS}

This study has been supported by the Scientific Research Project Coordination Center of Pamukkale University, Turkey (BAP Project Number: 2018SOBE007).

\section{Araştırmacıların Katkı Oranı Beyanı / Researchers' Contribution Rate Statement Yazarlar bu çalışmaya eşit şekilde katkı sağladıklarını beyan etmişlerdir. The authors declare that they have contributed equally to this article.}

\section{Araştırmacıların Çatışma Beyanı / Researchers'Conflict of Interest Statement}

Yazarlar, bu çalışmada potansiyel bir çıkar çatışması olmadığını beyan etmişlerdir. The authors declare that there is no potential conflict of interest in this study.

\section{REFERENCES}

Adıgüzel, Ü.D., Sarıtaş, E., Barutçu, S. (2017). “Sevimlilik Boyutlarının Derecelendirilmesi ve Sevimliliğin Satın Alma Davranışları Üzerine Etkisi: Ambalaj Tasarımı Üzerine Keşifsel Bir Araştırma", https://dergipark.org.tr/tr/pub/pjess/issue/35975/403648, (Erişim:10.05.2018).

Adıgüzel, Ü.D., Barutçu S. (2017). “Sevimlilik Algısının Satın Alma Davranışlarına Etkisi: Denizli'de Bir Araştırma", https://dergipark.org.tr/en/pub/dpusbe/issue/29857/321478, (Erişim: 10.05.2018). 
Aksoy, T. (2010). “Cool Olmak Ne Demek?”, www.temelaksoy.com.tr, (Erişim:11.04.2016).

Allison, A (2003). “Portable Monsters and Commodity Cuteness: Poke'mon As Japan's New Global Power", http://web.mit.edu/condry/Public/cooljapan/Feb23-2006/Allison-03Postcol-Portble.pdf, (Erişim: 20.06.2019).

Angier, N. (2006). “The Cute Factor”, www.nytimes.com/2006/01/03/science/03cute, (Erişim: 12.02.2016).

Areni, C. S., Kim, D. (1994). “The Influence of In-Store Lighting on Consumers' Examination of Merchandise In a Wine Store", International Journal of Research in Marketing, https://www.sciencedirect.com/science/article/abs/pii/016781169490023X, (Erişim: 18.11.2019).

Atak H. (2013). “On Maddeli Kişilik Ölçeği'nin Türk Kültürü'ne Uyarlanması”, https://toad.halileksi.net/sites/default/files/pdf/on-maddeli-kisilik-olcegi-toad.pdf, (Erişim: 18.11.2019).

Atkinson, R.L., Atkinson, R.C., Hilgard, E.R. (1995). Psikolojiye Giriş II, (çev: Kemal Atakay, Mustafa Atakay, Aysun Yavuz), İstanbul: Sosyal Yayınlar.

Babin, B.J., Darden, W.R., Griffin, M. (1994). “Work and/or Fun: Measuring Hedonic and Utilitarian Shopping Value", https:/academic.oup.com/jcr/articleabstract/20/4/644/1798609, (Erişim. 20.06.2018).

Ballantine, P.W., Jack, R., Parsons, A.G. (2010). “Atmospheric Cues and Their Effect on The Hedonic Retail Experience", https://www.emerald.com/insight/content/doi/10.1108/09590551011057453/full/html? mobileUi=0\&fullSc $=1 \& \mathrm{mbSc}=1 \&$ fullSc $=1 \&$ fullSc $=1$, (Erişim: 22.03.2020).

Barbaranelli, C, Caprara, G.V., Rabasca, A., Pastorelli, C. (2003). "A Questionnaire for Measuring the Big- Five in Late Childhood", https://www.sciencedirect.com/science/article/abs/pii/S019188690200051X, (Erişim: 22.03.2020).

Barutçu, S. ve Adıgüzel, Ü. D. (2015). “Sevimli Pazarlama Ve Maskotların Marka Farkındalığı Marka Bağlılığı ve Markaya Yönelik Tutum Üzerindeki Etkisi: Karşılaştırmalı Bir Araştırma", $\quad$ https://dergipark.org.tr/en/pub/eyad/issue/57413/813677, (Erişim: 12.04.2016).

Bellfield, J., Bimont, C., Blom, J., Dommeyer, C.J., Gardiner, K., Mathenia, E., Soto, J. (2011). "The Effect of a Cute Stimulus on Personally-Initiated, Self-Administered Surveys", http://marketing-bulletin.massey.ac.nz/V22/MB_V22_N1_Dommeyer.pdf, (Erişim: 25.06.2018).

Brougere, G. (2013). "Licensing and The Rhetoric of Fun: The Cute and The Cool", https://www.emerald.com/insight/content/doi/10.1108/YC-03-2013-00354/full/html, (Erişim: 25.06.2018).

Brown, S. (2010). “Where The Wild Brands Are: Some Thoughts on Anthropomorphic Marketing", 
https://www.ingentaconnect.com/content/westburn/tmr/2010/00000010/00000003/art0 0002, (Erişim: 25.06.2018).

Bryce, M. (2006). “Cuteness Needed: The New Language/Communication Device in a Global Society", http://ijh.cgpublisher.com/product/pub.26/prod.393, (Erişim:18.03.2019).

Burger, J.M. (2006). Kişilik, (çev: İnan Deniz Erguvan Sarığlu), İstanbul: Kaknüs Yayınları,

Can, A. (2017). SPSS ile Bilimsel Araştırma Sürecinde Nicel Veri Analizi, 5. Baskı, Ankara: Pegem Akademi.

Casidy, R. (2012). "An Empirical Investigation of the Relationship Between Personality Traits, Prestige Sensivity and Fashion Consciousness of Generation Y in Australia", https://www.sciencedirect.com/science/article/abs/pii/S1441358212000249, (Erişim: 20.02.2020).

Cheok, A. D., (2012)." Kawaii/Cute Interactive Media", https://link.springer.com/chapter/10.1007/978-1-84996-137-0_9, (Erişim: 20.02.2020).

Cheok, A. D., Ohkura, M., Fernando, O. N. N., Merritt, T. (2008). “Designing Cute Interactive Media", Innovation, 8,3: 8-9.

Chuang, T. (2005). “The Power of Cuteness”, Journal of East Asian Affairs, Summer: 21-28.

Cross, G. (2004). The Cute and The Cool: Wondrous Innocence and Modern American Children's Culture, NewYork Oxford University Press.

Dale, J.P. (2016). "Cute Studies: An Emerging Field", https://www.ingentaconnect.com/content/intellect/eapc/2016/00000002/00000001/art0 0002, (Erişim: 23.02.2020).

Decatur, M. A. (2012). “Consuming Cuteness in Japan: Hello Kitty, Individualism and Identity", Popular Anthropology Magazine, 3, 1: 1-4, (Erişim: 23.02.2020).

Demirbilek, O. (2006). Emotions and Desing, International Encyclopedia of Ergonomics and Human Factors, Second Edition. (e-book).

Demirbilek, O., Şener, B. (2003). "Product Design, Semantics and Emotional Response", https://www.tandfonline.com/doi/abs/10.1080/00140130310001610874, (Erişim: 12.04.2019).

Demirci M.K., Özler D.E., Girgin B. (2009). “Beş Faktör Kişilik Modelinin İşyerinde Duygusal Tacize (Mobbing) Etkileri: Hastane İşletmelerinde Bir Uygulama”, https://jhsskhazar.org/2009-12-2/BES\%20FAKTOR\%20KISILIK\%20MODELININ.pdf, (Erişim: 23.04.2019).

Digman, J. M., Takemoto-Chock, N. K. (1981). “Factors In The Natural Language Of Personality: Re-Analysis, Comparison, And Interpretation Of Six Major Studies", https://www.tandfonline.com/doi/abs/10.1207/s15327906mbr1602_2, (Erişim: 23.04.2018).

Epley, N., Akalis, S., Waytz, A., Cacioppo, J. T. (2008). “Creating Social Connection Through Inferential Reproduction: Loneliness And Perceived Agency In Gadgets, Gods, And 
Greyhounds", https://journals.sagepub.com/doi/abs/10.1111/j.1467-9280.2008.02056.x, (Erişim: 18.02.2019).

Eren, E. (2006). Örgütsel Davranış ve Yönetim Psikolojisi, İstanbul: Beta Yayıncılık.

Eroğlu, F. (2015). Davranış Bilimleri, İstanbul: Beta Yayıncılık.

Feist, J., Feist, G.J. (2008). Theories of Personality (7th Edition), McGraw-Hill Primis.

Fraj, E., Martinez, E. (2006). "Influence of Personality on Ecological Consumer Behaviour", https://onlinelibrary.wiley.com/doi/abs/10.1002/cb.169, (Erişim: 18.02.2019).

Glocker, M. L., Langleben, D. D., Ruparel, K., Loughead, J. W., Gur, R. C., Sachser, N. (2009). "Baby Schema in Infant Faces Induces Cuteness Perception and Motivation for Caretaking in Adults", https://onlinelibrary.wiley.com/doi/abs/10.1111/j.14390310.2008.01603.x, (Erişim: 18.02.2019).

Gn, J. (2016). “A Lovable Metaphor: On The Affect, Language and Design of 'Cute'”, https://www.ingentaconnect.com/content/intellect/eapc/2016/00000002/00000001/art0 0005, (Erişim: 15.02.2019).

Granot, E., Alejandro, B., Russell, T.M.L. (2014). “A Socio-Marketing Analysis of The Concept of Cute and Its Consumer Culture Implications", https://journals.sagepub.com/doi/abs/10.1177/1469540513485274, (Erişim: 15.02.2019).

Guido,G., Peluso, A.M., Capesto, M., Miglietta, M. (2015). “An Italian Version of the 10 Item Big-Five Inventory: An Application to Hedonic and Utilitarian Shopping Values", https://www.sciencedirect.com/science/article/abs/pii/S0191886914007028, (Erişim: 01.04.2019).

Gülerarslan, A., (2011). "Tüketici Olarak Çocuk ve Ailenin Satın Alma Kararlarına Etkisi”, https://dergipark.org.tr/en/pub/josc/issue/19022/200610, (Erişim: 01.04.2019).

Hellen, K., Saaksjarvi M. (2013). “Development of a Scale Measuring Childlike Anthropomorphism in Products", https://www.tandfonline.com/doi/abs/10.1080/0267257X.2012.759989,(Erişim: 01.04.2019).

Hildebrandt K., Fitzgerald H.E. (1978). “Adult's Responses to Infants Varying in Perceived Cuteness", https://www.sciencedirect.com/science/article/abs/pii/0376635778900426, (Erişim: 03.04.2019).

Hu, Y., Kim, H.J. (2018). “Positive and Negative e-WOM Motivations And Hotel Customers' Ewom Behavior: Does Personality Matter?", https://www.sciencedirect.com/science/article/abs/pii/S0278431917300579, (Erişim: 13.04.2020).

İnanç, Y.B., Yerlikaya, E.E. (2011). Kişilik Kuramları, İzmir: Pegem Akademi.

John, O. P., Srivastava, S. (1999). “The Big-Five Trait Taxonomy: History, Measurement, And Theoretical Perspectives", Handbook Of Personality: Theory And Research, (edit. L. A. Pervin \& O. P. John), 2: 102-138, New York: Guilford Press. 
Karraker, H.K, Stern, M. (1990). “Infant Physical Attractiveness and Facial Expression: Effects on Adult Perceptions", https://www.tandfonline.com/doi/abs/10.1207/s15324834basp1104_2, (Erişim: 13.04.2020).

Kato, M (2002). “The Japanese Obsession With Adorable Icons is Rooted in Cultural Tradition", www.eyemagazine.com/feature/article/cute-culture, (Erişim: 25.04.2018).

Kinsella, S. (1995). Cuties in Japan. In Women, Media and Consumption in Japan, Honolulu University of Hawaii Press.

Koç, E. (2012). Tüketici Davranışı ve Pazarlama Stratejileri, Ankara: Seçkin Yayıncılık.

Komatsu, T., Ohkura, M. (2011). Study on Evaluation of Kawaii Colors Using Visual Analog Scale, Human Interface (edit. M.J. Smith, G. Salvendy), Part I,103-108.

Kovarovic, S. (2011). "Hello Kitty: A Brand Made of Cuteness", http://services.library.drexel.edu/static_files/dsmr/Kovarovic\%20Final.pdf, (Erişim: 10.03.2020).

Kotler P., Armstrong, G. (2016). Principles of Marketing, Edinburgh: Pearson.

Lee, D. (2005). "Inside Look at Japanese Cute Culture", www.uniorbblog.blogspot.com/2017/01, (Erişim: 01.12.2017).

Lin, L. (2010). “The Relationship of Consumer Personality Trait, Brand Personality and Brand Loyalty: An Empirical Study of Toys and Video Games Buyers", https://www.emerald.com/insight/content/doi/10.1108/10610421011018347/full/html, (Erişim: 12.01.2020).

Liu, Z., Xu, A., Wang, Y., Schoudt, J., Mahmud, J., Akkiraju, R. (2017). “Does Personality Matter? A Study of Personality and Situational Effects on Consumer Behavior", HT'17, July 4-7, Prague, Czech Republic, 185-193, https://dl.acm.org/doi/abs/10.1145/3078714.3078733, (Erişim: 12.01.2020).

Lobmaier, J.S., Sprengelmeyer, R. (2010). “Female and Male Responses To Cuteness, Age and Emotion In Infant Faces", https://www.sciencedirect.com/science/article/abs/pii/S1090513809000531, (Erişim: 12.01.2020).

Marcus, A. (2002). "The Cult of Cute: The Challenge of User Experience Design", https://dl.acm.org/doi/fullHtml/10.1145/581951.581966, (Erişim: 13.01.2020).

McCrae, R.R., Sutin, A.R. (2009). “Openness To Exprience”, (Edit. Mark R. Leary, Rick H. Hoyle), Handbook of Individual Differences in Social Behavior, Chapter. 17, 257-273, London: Guilford Press.

McCrae, R.R., Costa, P.T. (2008). “The Five-Factor Theory of Personality”, (Edit. Oliver P. John Richard W. Robins Lawrence A. Pervin), Handbook of Personality, 3Th Edition, Chapter. 5,159-181, London: Guilford Press. 
McDougall, J., Chantrey D. (2004). "The Making Of Tomorrow's Consumer", https://www.emerald.com/insight/content/doi/10.1108/17473610410814283/full/html, (Erişim: 13.01.2020).

McVeigh, J.B. (2000). "How Hello Kitty Commodifies The Cute, Cool and Camp", https://journals.sagepub.com/doi/abs/10.1177/135918350000500205,

(Erişim: 13.01.2020).

Morgan, C.T. (2010). Psikolojiye Giriş, (çev: Sirel Karakaş, Rükzan Eski), Konya: Eğitim Kitabevi Yayınları.

Morgan, G.A., Leech, N.L., Gloeckner, G.W., Barrett, K.C. (2011). IBM SPSS For Introductory Statistics Use and Interpretation, 4th Edition, New York: Routledge,

Mowen, J.C., Spears, N. (1999). “Understanding Compulsive Buying Among College Students: A Hierarchical Approach", https://www.sciencedirect.com/science/article/abs/pii/S1057740899703608, (Erişim: 14.01.2020).

Möller, J. (2009). Cuteness As a Form of Communication. An On-Line Experience, (Master of Communication Thesis), University of Gothenburg, https://gupea.ub.gu.se/handle/2077/26741, (Erişim: 14.01.2018).

Mulyanegara, R.C., Tsarenko, Y., Anderson, A. (2009). “The Big Five and Brand Peersonality: Investigating the Impact of Consumer Personality on Preferences Towards Particular Brand Personality", https://link.springer.com/article/10.1057/palgrave.bm.2550093, (Erişim: 04.05.2020).

Nenkov, Y. G., Scott, L. M. (2014). “So Cute I Could Eat It Up: Priming Effects of Cute Products on Indulgent Consumption", https:/academic.oup.com/jcr/articleabstract/41/2/326/2907555, (Erişim: 16.04.2019).

Ngai, S. (2005). "The Cuteness of The Avant-Garde", https://www.journals.uchicago.edu/doi/abs/10.1086/444516, (Erişim: 16.04.2019).

Nittono, H., Fukushima, M., Yano, A., Moriya, H. (2012). “The Power of Kawaii: Viewing Cute Images Promotes a Careful Behavior and Narrows Attentional Focus", https://journals.plos.org/plosone/article?id=10.1371/journal.pone.0046362\&_hstc=171 738815.2fdd7a7debc8575bac5a80cf7e168316.1476662400122.1476662400123.1476662400 124.1\&_hssc=171738815.1.1476662400125\&_hsfp=1773666937, (Erişim: 16.04.2019).

Nye, J. (2006). "Transformational Leadership and U.S. Grand Strategy", https://heinonline.org/HOL/LandingPage?handle=hein.journals/fora85\&div=67\&id=\& page, (Erişim: 16.04.2019).

Ohkura, M., Konuma, A., Murai, S., Aoto, T. (2008). "Systematic Study for “Kawaii" Products (The Second Report) - Comparison of "Kawaii" Colors and Shapes", SICE annula Conference, 20-22 August, The University Electro- Communications, Japan, https://ieeexplore.ieee.org/abstract/document/4654703, (Erişim: 16.04.2019).

Otero-Lopez, J. M., Pol, E. V. (2013). “Compulsive Buying and Five Factor Model of Personality:

A Facet Analysis", 
https://www.sciencedirect.com/science/article/abs/pii/S0191886913002092, (Erişim: 13.02.2019).

Özsoy, E., Erol, E., Korkutat, A.A., Şeker, M. (2014). “Kişilik Modelleri Boyutlarının Karşılaştırılması: A Tipi ve B Tipi Kişilik ve Beş Faktör Kişilik Modeli", Uluslararası Hakemli Beşeri ve Akademik Bilimler Dergisi, C.3, S.9: 104-116.

Paunonen, S. V., Ashton, M.C. (2001). "Big Five Factors and Facets and The Prediction of Behavior", https://psycnet.apa.org/record/2001-18127-012, (Erişim: 10.02.2020).

Papanek, V. (1995). The Green Imperative: Natural Design fort he Real World, London: Thames and Hudson.

Park, C.W., Gratiana, P., Jia, H.M. (2013) ,"I’Ll Keep the Cuddly One: Effects of Cuteness Versus Elegance Product Retention", https://www.acrwebsite.org/volumes/v41/acr_v41_15254.pdf, (Erişim: 05.05.2020).

Pittenger, D. (2004). “The Limitations of Extracting Typologies From Trait Measures of Personality",

https://www.sciencedirect.com/science/article/abs/pii/S0191886903004082, (Erişim: 05.05.2020).

Robbins, S.P., Judge, T.A. (2013). Organizational Behavior, (15th Edition), Edinburgh: Pearson.

Scott, M.L., Nenkov, G.Y. (2016). “Using Consumer Responsibility Reminders To Reduce Cuteness-Induced Indulgent Consumption", https://link.springer.com/article/10.1007\%252Fs11002-014-9336-8, (Erişim: 06.05.2020).

Solomon, M.R. (2013). Consumer Behavior Buying, Having and Being, (10th Edition), Edinburgh: Pearson.

Solomon, M.R., Bamossy, G.J., Askegaard, S.T., Hogg, M.K. (2013). Consumer Behaviour A European Perspective, (5th Edition), Edinburgh: Pearson.

Soltani, A., Johannes, P., Young, J., Sun, Z. (2018). “Exploring City Branding Strategies And Their Impacts on Local Tourism Success, The Case Study of Kumamoto Prefecture, Japan", https://www.tandfonline.com/doi/abs/10.1080/10941665.2017.1410195, (Erişim: 01.05.2020).

Storey, A.E., Walsh, C.J., Quinton, R.L., Wynne-Edwards, K.E. (2000). “Hormonal Correlates of Paternal Responsiveness in New And Expectant Fathers. Evolution and Human Behavior", https://www.sciencedirect.com/science/article/abs/pii/S1090513899000422, (Erişim: 01.05.2020).

Sweeny, J.C., Soutar, G.N. (2001). “Consumer Perceived Value: The Development of a Multiple Item Scale", https://www.sciencedirect.com/science/article/abs/pii/S0022435901000410, (Erişim: 03.03.2018).

Tai, K., Zheng, X., Narayanan, J. (2011). “Touching a Teddy Bear Mitigates Negative Effects of Social Exclusion to Increase Prosocial Behavior", https://journals.sagepub.com/doi/abs/10.1177/1948550611404707, (Erişim: 02.04.2020). 
Taylor, A. (2011). "10 Cutest Cars in America", Fortune, www.archive.fortune.com/galleries/2011/autos, (Erişim:10.10.2017).

Wang, T. (2014). “Motivational Antecedents and Behavioral Consequences of Cuteness in Marketing", (The Doctor of Philosophy in Marketing Thesis), The Hong Kong University of Science and Technology, https://repository.ust.hk/ir/Record/1783.172531, (Erişim:10.10.2017).

Wen, M. L.Y., Li, H.S. (2013). “A Study on The Relationship Amidst Health Consciousness, Ecological Affect And Purchase Intention of Green Production", https://www.ijoionline.org/attachments/article/34/FINAL\%20ISSUE\%20VOL\%205\%20NUM\%204\%20 APRIL\%202013.pdf\#page=124, (Erişim: 23.05.2020).

Yoo, B., Donthu, N. (2001). “Developing and Validating A Multidimensional Consumer-Based Brand Equity Scale", https://www.sciencedirect.com/science/article/abs/pii/S0148296399000983, (Erişim: 23.04.2017).

Zhipeng, X., Tao, W., Jing, Z. (2018). "A Literature Review of Cuteness in Marketing", https://qks.sufe.edu.cn/J/WJGL/Article/Details/A0wgijygl-40-5-xiezhipeng, (Erişim: 20.06.2020). 